\title{
The Ozonation Process for Increasing Value Added Tallow of Cow as A Polyol
}

\author{
Linda Aliffia Yoshi ${ }^{1, a}$, Nadya Fitria ${ }^{1}$, Naufal Rozin Albana ${ }^{1}$, Enjarlis ${ }^{1}$, Agam Duma K.W ${ }^{1}$ \\ ${ }^{1}$ Program Studi Teknik Kimia, Institut Teknologi Indonesia \\ Jalan Raya Puspiptek Serpong, Tangerang Selatan \\ a linda.aliffia@iti.ac.id
}

\begin{abstract}
The purpose of this research is to produce polyol, through the ozonation process and to find the best catalysts and solvents for the formation of hydroxyl group. The hydroxyl group is indicator of the formation polyol. The process of making polyols is unsaturated fatty acids of the cow through the process of ozonation, using the solvents of sorbitol and glycerol, as well as catalysts of sulfuric acid and sodium hydroxide. The reaction temperature is run at $50^{\circ} \mathrm{C}$ and ozone levels are 4.33, 4.795, 5.021, 5.480 grams. The best results used a glycerol solvent, a sodium sulfate catalyst, and a 5.48 gram ozon content.
\end{abstract}

Keywords-Component; Tallow, Polyol, Glycerol, Sodium sulfate, Ozon

\section{Introduction}

One cow weighing $400 \mathrm{~kg}$ will get a carcass (a part of the animal's body that has been slaughtered, whole, or cleaved along the spine, only the head, legs, skin, internal organs (viscera), and tail separated) in the form of fat (tallow) around 96-100 kg [1]. From this number, tallow will be able to produce about $25 \%$ of one cow with ideal weight. Meanwhile according to Lusiana Mustinda [2], in 100 grams of beef contains 14 grams of tallow. Tallow is a by-product from slaughtering cows. Tallow is still considered as cutting waste because its utilization has not been maximized. Currently, the use of tallow as food has begun to be abandoned due to the consideration of high saturated fat content. Food with high saturated fat content is considered a trigger for the narrowing of blood vessels. Besides, fat which relatively contains many unsaturated double bonds, will experience oxidation and form an unpleasant rancid odor so that its existence is often disputed [3]. This potential situation is the reason for the need for technology in the use of tallow to be used as raw material with more value.

Tallow has been widely used as a raw material for making soap because of the high stearic acid content in tallow can act as a soap hardener. Whereas in addition to being used as a raw material for making soap, tallow has the potential as a raw material for making polyols. Polyols are organic compounds that have more than one hydroxyl group, and in the material, the industry is widely used as intermediate and additive materials [4]. The amount of FFA (Free Fatty Acid) from tallow is between $0.75-0.7 \%$. The titer point of tallow is generally above $40^{\circ} \mathrm{C}$. The main content of tallow is unsaturated fatty acids $43-49 \%$ (oleic acid $40-45 \%$, and linoleic acid 3-4\%) and saturated fatty acids $40.2-64 \%$ (palmitic acid 24-37\%, stearic acid $14-19 \%$, myristic acid 2-8\%, and lauric acid 0.2\%) [5]. Because it has a large enough unsaturated fatty acid content in Tallow, Tallow can be used as a raw material for polyols through the ozonation process with the help of sorbitol or glycerol solvents. The use of polyols in the cosmetics world is as a substitute for non-natural moisturizers for skin cell tissue.

Application of ozonation technology in polyol synthesis using tallow with process conditions at $50^{\circ} \mathrm{C}$, ozonation time 54 hours, ozone content 4.32 gram, and fat ratio with solvent $0.75: 1$. The optimum process conditions at the hydroxyl number of $68.08 \mathrm{mg}$ $\mathrm{KOH} /$ gram polyols are obtained so that they meet the minimum standard polyols that can be used in the manufacture of cosmetics [6]. In addition to ozonation technology, epoxidation methods can also be used for polyol synthesis. In 2014 Murniati et al [7] synthesized polyols from walnut seed oil and obtained the highest conversion percentage in the use of bentonite catalysts because in the epoxidation reaction the bentonite catalyst was able to degrade the group of oxygen quite high. Therefore this research aims is to produce polyols through the ozonation process and to find the best catalyst and solvent for the formation of hydroxyl groups. 


\section{Research Methodology}

The study was conducted using a series of ozonation devices presented in Figure 1 and the material used presented in Table 1.

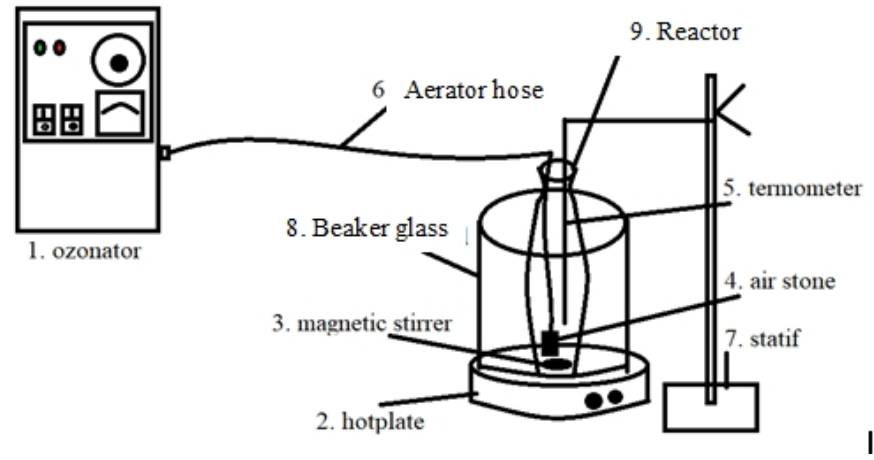

Figure 1. Series of ozonation tools

Table 1. Research material

\begin{tabular}{|l|l|}
\hline Material & Spesification \\
\hline Tallow & Solids \\
\hline Sorbitol & Liquid (70\%) \\
\hline Glycerol & Liquid \\
Sulfuric acid & Liquid (98\%) \\
\hline Sodium Hydroxide & Solid (technical grade) \\
\hline Sodium Carbonate & Solid (technical grade) \\
\hline Silica Gel & Solid (technical grade) \\
\hline Kalium Iodida & Solid \\
\hline Sodium Thiosulfate & Solid \\
\hline Potassium Hydroxide & Solid \\
\hline Acetic acid & Solid \\
\hline Pyridin & Solid \\
\hline Acetic Acid & Liquid \\
\hline
\end{tabular}

The study was conducted by varying ozone levels (4.33; 4.795; 5.021; 5.480 grams), catalysts $\left(\mathrm{H}_{2} \mathrm{SO}_{4}\right.$ and $\mathrm{NaOH}$ ), solvents (sorbitol and glycerol) by setting the operating temperature $\left(50^{\circ} \mathrm{C}\right)$, catalyst volume $(1 \%)$, and reactor volume $(250 \mathrm{ml})$. Research parameters observed were hydroxyl numbers (BOH), acid numbers, and iodic numbers by testing through FTIR and NMR analysis. The research scheme refers to Figure 2.

The steps to do the research scheme began with the preparation of raw materials (liquefaction), followed by determining the best solvents (sorbitol and glycerol). The best results were followed by the selection of the best catalyst with the appropriate variable ozonation dose. The ozonation results were then measured parameters and analyzed using FTIR and NMR (Figure 3).

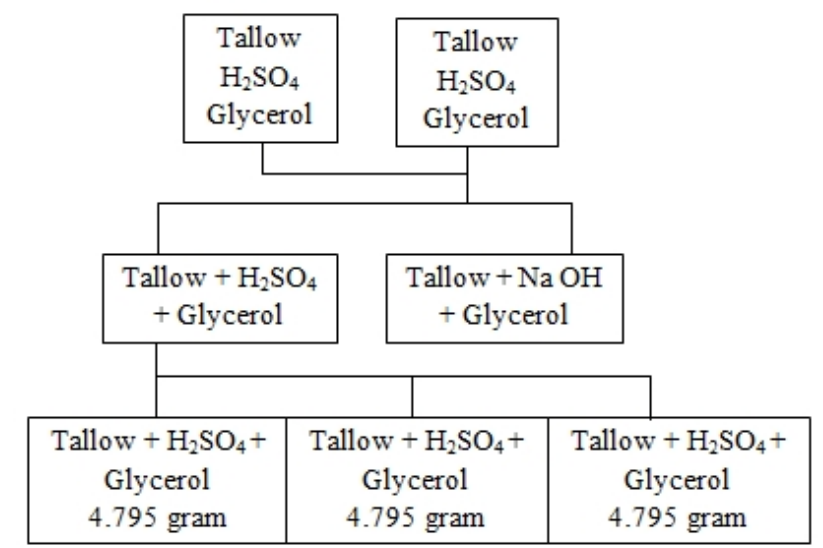

Figure 2. Research sceme

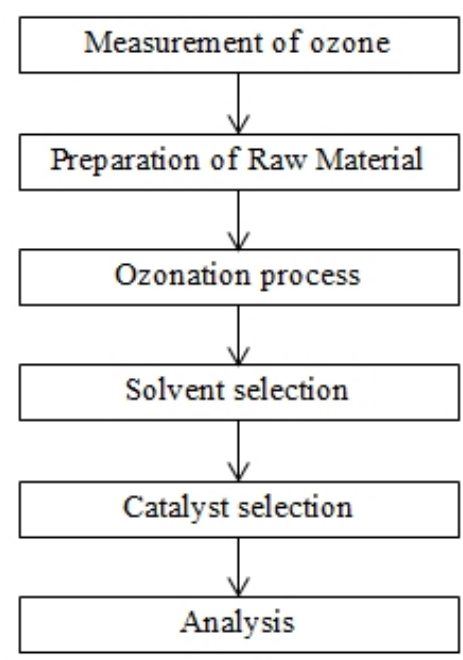

Figure 3. Flow chart

\section{Results and Discussion}

\section{A. Effect of Solvent on Polyols}

The solvent used is glycerol while the sorbitol solvent refers to the research of Adha \& Gibson [6].

Table 2. Effect of Solvent on BOH number

\begin{tabular}{|l|r|r|r|}
\hline Solvent & $\begin{array}{c}\text { Temperature } \\
\left({ }^{\circ} \mathrm{C}\right)\end{array}$ & $\begin{array}{c}\text { Ozone } \\
\text { content } \\
\text { (gram) }\end{array}$ & $\begin{array}{c}\text { mg.KOH/gram } \\
\text { polyol }\end{array}$ \\
\hline Sorbitol & 50 & 4.33 & 68.08 \\
\hline Glycerol & 50 & 4.33 & 72.56 \\
\hline
\end{tabular}

The hydroxyl value produced by the glycerol solvent is higher than the sorbitol at the same temperature and ozone levels. This shows that the use of glycerol solvents is better used in the manufacture of polyol because glycerol is a major component of all fats and oils, in the form of esters called glycerides. The hydroxyl number produced by glycerol is higher in the manufacture of 
polyol from vegetable fat at $200^{\circ} \mathrm{C}$ with an epoxidation time of 2.5 hours produced by $\mathrm{BOH}$ of $93.82 \mathrm{mg}$ $\mathrm{KOH} / \mathrm{gram}$ polyol [8]. A triglyceride molecule consists of one glycerol molecule combined with three fatty acid molecules. Triglycerides are the largest ingredient in oils or fats, which are components that are highly desirable to be reacted with glycerol. The reaction of triglyceride formation from glycerol with fatty acids is shown in Figure 4. The double bond found in the polyol is broken and the glycerol reacts to the polyol ester so that the number of polyol esters formed is directly proportional to the hydroxyl number.

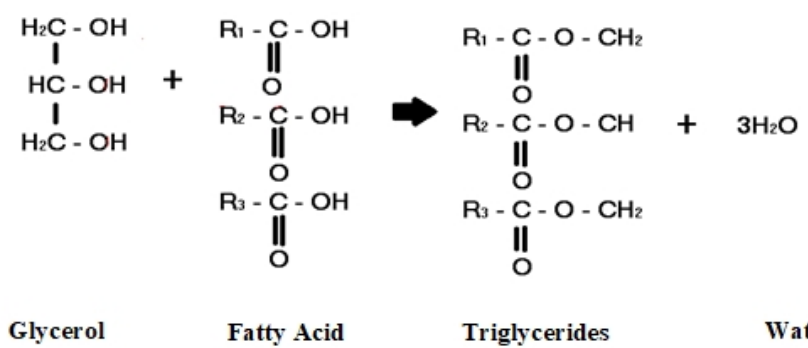

Figure 4. Reaction of Triglyceride Formation from Glycerol with Fatty Acid

If the fatty acids are reacted with sorbitol, the reaction will be imperfect because the amount of carbon in sorbitol is 6 while the fatty acid itself only has 3 carbon. So when reacted using sorbitol as if reacting with 2 glycerol (Figure 5).

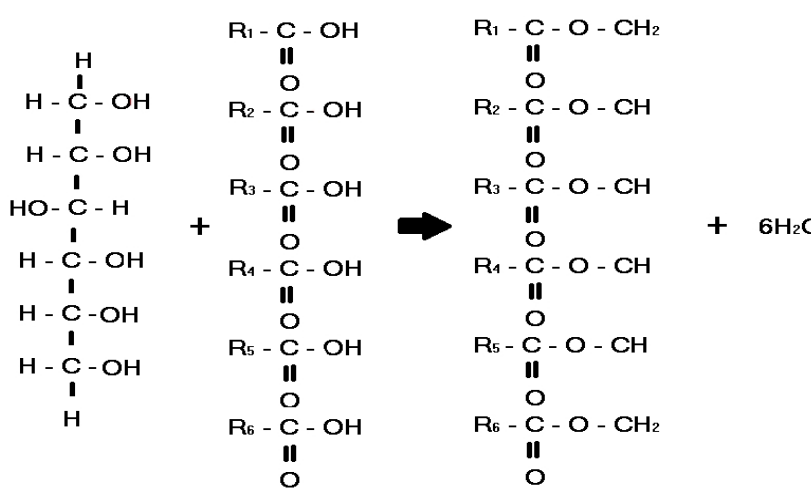

Figure 5. Reaction of Triglyceride Formation from Glycerol with Fatty Acid

\section{B. Effects of Catalysts on Polyol}

A chemical reaction can take place because of reactant molecules at a certain time experience an active state that is if the energy of the molecule is in an activation energy state. In this way, the chemical bonds in the molecule can break so that the product is formed. The function of the catalyst is to accelerate chemical reactions by reducing its activation energy [8].
Table 3. Effect of Catalyst on BOH Produced

\begin{tabular}{|l|r|r|r|}
\hline Catalyst & $\begin{array}{c}\text { Temperature } \\
\left({ }^{\circ} \mathrm{C}\right)\end{array}$ & $\begin{array}{c}\text { Ozone } \\
\text { content } \\
(\mathrm{gr})\end{array}$ & $\begin{array}{c}\mathrm{BOH} \\
\mathrm{mgKOH} / \mathrm{gram} \\
\text { poliol }\end{array}$ \\
\hline $\mathrm{H}_{2} \mathrm{SO}_{4}$ & 50 & 4.33 & 72.56 \\
\hline $\mathrm{NaOH}$ & 50 & 4.33 & - \\
\hline
\end{tabular}

$\mathrm{H}_{2} \mathrm{SO}_{4}$ catalysts under the same temperature and ozone levels in $\mathrm{mg} \mathrm{KOH} /$ gram polyol can be used in the process of bio polyol synthesis from beef tallow through the ozonation process. This condition is due to ozone having a stable ability under acidic conditions so that ozone is easier to break double bonds. This is reinforced in the research conducted by [6] catalysts used to obtain the best results in the initial study of bio polyol synthesis from beef fat, $\mathrm{H}_{2} \mathrm{SO}_{4}$ catalysts with a hydroxyl number of $68.08 \mathrm{mgKOH} / \mathrm{gram}$ polyol. Research conducted by Galuh \& Hanafi (2008) [9] esterification of lauric acid with glycerol was reversible when catalyzed by acid because acid catalysts cause carboxylic acids to become conjugated. Esterification reaction with $1 \% \mathrm{H}_{2} \mathrm{SO}_{4}$ catalyst can optimize the production of methyl esters due to the presence of proton $\left(\mathrm{H}^{+}\right)$which is owned by $\mathrm{H}_{2} \mathrm{SO}_{4}$, and it is easier to release protons because it is fully ionized $(\alpha=1)$. The advantage of using an acid catalyst compared to an alkaline catalyst is that it remains effective as long as the reaction takes place in oil which still contains free fatty acids, but has a disadvantage when separating the reaction product. The more $\mathrm{H}_{2} \mathrm{SO}_{4}$ is added, the faster the epoxidation reaction takes place, but the oxygen obtained is getting lower. This is caused by the addition of concentrated $\mathrm{H}_{2} \mathrm{SO}_{4}$ which can increasingly accelerate the degradation of the oxidant group. Concentrated sulfuric acid which is still present in the aqueous phase can be a catalyst for the degradation of the oxidant group through side reactions in the form of hydroxylation reactions and the formation of ketone compounds and can be seen in Figure 6.

$$
\text { A. } \mathrm{R}_{1}-\mathrm{HC}-\prod_{\mathrm{O}}^{\mathrm{CH}-\mathrm{R}_{2}}+\mathrm{H}_{2} \mathrm{O} \longrightarrow \mathrm{H}^{+} \longrightarrow \mathrm{R}_{\mathrm{OH}}-\left.\right|_{\mathrm{OH}} ^{\mathrm{CH}}-\mathrm{R}_{1}^{\mathrm{CH}}-\mathrm{R}_{2}
$$

Figure 6. The Hydroxylation Reaction (A) and the Reaction of The Ketone Compound (B) in the Epoxidation using $\mathrm{H}_{2} \mathrm{SO}_{4}$

$\mathrm{NaOH}$ catalyst cannot produce hydroxyl numbers, because the desired product becomes soap. This is because the saponification reaction occurs, 
saponification is a hydrolysis reaction between an alkaline base and fatty acids that will produce glycerol and salt called fatty acid soap used, which is unsaturated fatty acids because it has at least one double bond between the constituent carbon atoms and is less stable so it is easy to react with other elements. Soap is an alkaline salt of high tribal fatty acids so that it will be partially hydrolyzed by water. Therefore the soap solution in water is alkaline. Triglyceride mixture is processed into soap through the saponification process with sodium hydroxide solution liberating glycerol. Saponification reaction using alkali is triglyceride reaction with alkali $(\mathrm{NaOH}$ or $\mathrm{KOH})$ which produces soap and glycerin. In a study conducted by Wara \& Rosidah (2012) [10] was used $1 \% \mathrm{NaOH}$ catalyst in the manufacture of biodiesel from a mixture of beef tallow (Beef Tallow) and palm oil with a mole ratio of oil and methanol 1:6 then produces methyl esters which are transesterified oils.

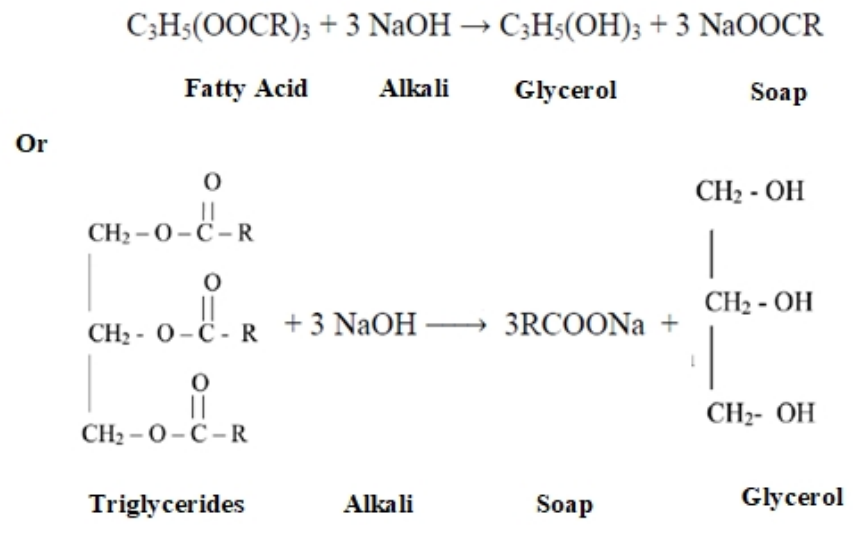

Figure 7. Saponification Reaction using $\mathrm{NaOH}$

\section{Effect of Ozone on Formed Polyol}

Table 4. Effect of Ozone on Formed Polyol

\begin{tabular}{|c|c|r|r|}
\hline $\begin{array}{c}\text { Ozon } \\
\text { content } \\
\text { (gram) }\end{array}$ & $\begin{array}{c}\text { Iod number } \\
\text { (iod/100 gram } \\
\text { sample) }\end{array}$ & $\begin{array}{c}\text { Acid number } \\
\text { (mgKOH/gram } \\
\text { sample) }\end{array}$ & $\begin{array}{c}\text { BOH } \\
\text { (mgKOH/ } \\
\text { gram poliol) }\end{array}$ \\
\hline 4.33 & 49.068 & 0.321 & 72.559 \\
\hline 4.795 & 43.146 & - & 81.154 \\
\hline 5.021 & 38.239 & - & 84.520 \\
\hline 5.480 & 29.779 & - & 86.764 \\
\hline
\end{tabular}

The table shows that the more ozone levels reacted in the polyol. the more bonds are broken and glycerol reacts to polyol esters. The more polyol esters formed. the higher the number of hydroxyls produced. This is made clear by Haifan (2017) [11] through the mechanism of ozonation reactions in fats to produce polyol where at low ozonation temperatures and high ozone levels are used to maintain the solubility of ozone in these fats or oils so that the hydroxyl number will increase. The higher the hydroxyl number of the polyol shows the quality of the polyol. the better the quality of the polyol. The higher the hydroxyl number. the greater the $\mathrm{OH}$ group which will make the molecular weight bigger $[8,12]$. The increase in hydroxyl number of the amount of ozone contained in polyols is inversely proportional to the number of acids produced. Acid numbers indicate the amount of free fatty acids present in the oil [12]. Large acid numbers indicate large free fatty acids derived from oil hydrolysis or due to poor processing. The higher the acid value the lower the quality.

The increase in ozone levels used for the ozonation process results in a decrease in acid numbers. Even the ozone level is more than 4.33 gram. there are no free fatty acids in polyols. In a study conducted by Murniati et al (2014) [7]. the acid number on the $\mathrm{H}_{2} \mathrm{SO}_{4}$ catalyst increased from the original walnut seed oil before epoxidation of $7.21 \mathrm{mg} \mathrm{KOH} / \mathrm{oil}$ with $\mathrm{H}_{2} \mathrm{SO}_{4}$ catalyst to $23.07 \mathrm{mg} \mathrm{KOH} /$ gram oil with other catalysts decreased. at catalyst $\mathrm{HCl}$ the acid number is $1.12 \mathrm{mgKOH} / \mathrm{gram}$ oil and the Bentonite catalyst is $0.90 \mathrm{mgKOH} / \mathrm{gram}$ oil.

The effect of ozone levels on iod numbers produced also decreased with increasing levels of ozone given. The decrease in the iodic number is due to the termination of the double bond with increasing time of ozonation. A high iodine number indicates the unsaturation of a high oil or fat. The amount of iodine absorbed indicates the number of double bonds or unsaturated bonds. In a study conducted by Sri Seno Murniati et al (2014) [7] a decrease in iod number occurred. the iodine seed oil iod number was $111.50 \mathrm{iod}$ $/ 100$ gram after oil became polyol through the epoxidation process with different catalysts. the iodic number decreased with a catalyst $\mathrm{H}_{2} \mathrm{SO}_{4}$ iod number of $84.22 \mathrm{iod} / 100$ gram oil. $\mathrm{HCl}$ catalyst at $66.92 \mathrm{iod} / \mathrm{gram}$ oil and Bentonite at $30.82 \mathrm{iod} / 100$ gram oil.

\section{FTIR analysis}

The formed polyols were characterized using Fourier Transform Infra-Red (FTIR). This characterization aims to determine the location of $\mathrm{OH}$ groups formed from the results of conversion into polyol. The ozonation reaction that occurs in the alkene groups in bovine fat will decrease with the increase of $\mathrm{OH}$ groups in the product. with the increase in $\mathrm{OH}$ groups indicating an increase in the number of polyol. 


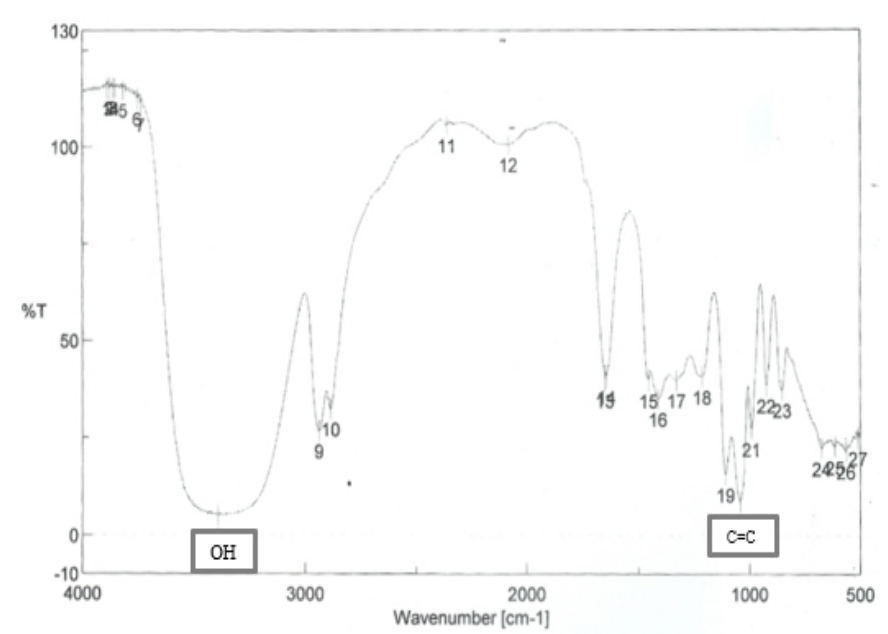

Figure 7. Wave number vs $\% \mathrm{~T}$ poliol

From the peak of absorption produced it can be seen that the formation of $\mathrm{O}-\mathrm{H}$ functional groups and alkene groups $(\mathrm{C}=\mathrm{C})$ in polyol products. The $\mathrm{O}-\mathrm{H}$ function group formed can be seen at wave number $3389.76 \mathrm{~cm}^{-1}$ with absorbance 1.2941. The peak absorption results were also seen in the alkene group $(\mathrm{C}=\mathrm{C})$ formed at wave number $1043.3 \mathrm{~cm}^{-1}$ with an absorbance of 1.0655 . From these data. it can be seen that the absorbance value of the alkene group is smaller than the hydroxyl group. This shows that the decreasing alkene bond forms an increased hydroxyl $(\mathrm{OH})$ group based on the FTIR test. Polyol synthesis was successful because of the absorbance of the alkene absorbance and the increase in the absorbance of the hydroxyl group.

\section{E. NMR analysis}

NMR spectrometry is used to find out more about functional groups that change in the formed polyol product. One parameter that can help interpret NMR spectra is the chemical shift. ${ }^{1} \mathrm{H}-\mathrm{NMR}$ spectrophotometer aims to determine the number of hydrogen atoms in the polyol formed. Measurement with this spectrophotometer is done with methanol solvent. The 1H-NMR spectrum is shown in Figure 8.

Chemical shifts for the synthesis of polyols from bovine fat at $3.696 \mathrm{ppm}$ indicate the presence of ${ }^{1} \mathrm{H}$ atoms in the $\mathrm{OH}$ group. Whereas based on the literature obtained by polyol compounds in general. the $1 \mathrm{H}$ atom in the $\mathrm{OH}$ group is at $3.65 \mathrm{ppm}$. These results indicate the number of hydrogen atoms in the synthesis compared with the number of hydrogen atoms from the literature is not much different.

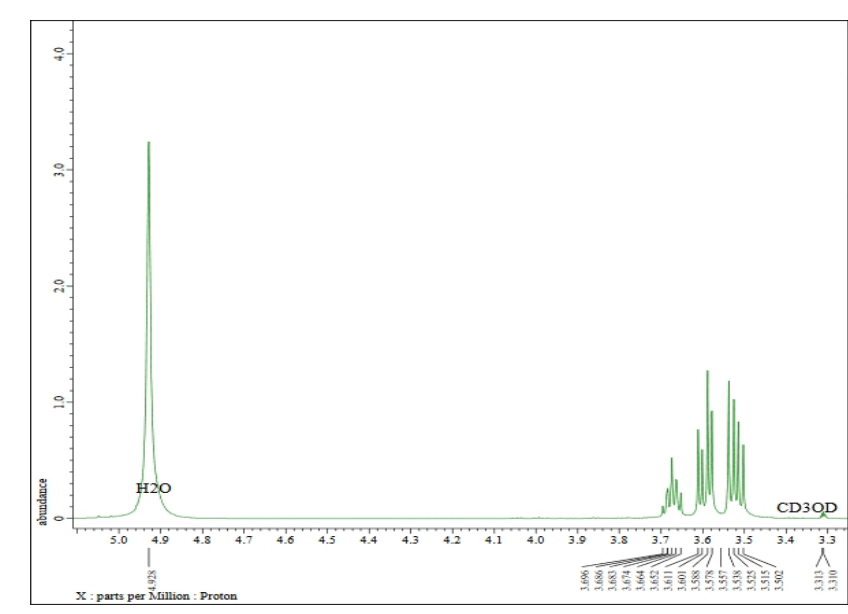

Figure $8 .{ }^{1} \mathrm{H}-\mathrm{NMR}$ spectrum of syntesis of polyol

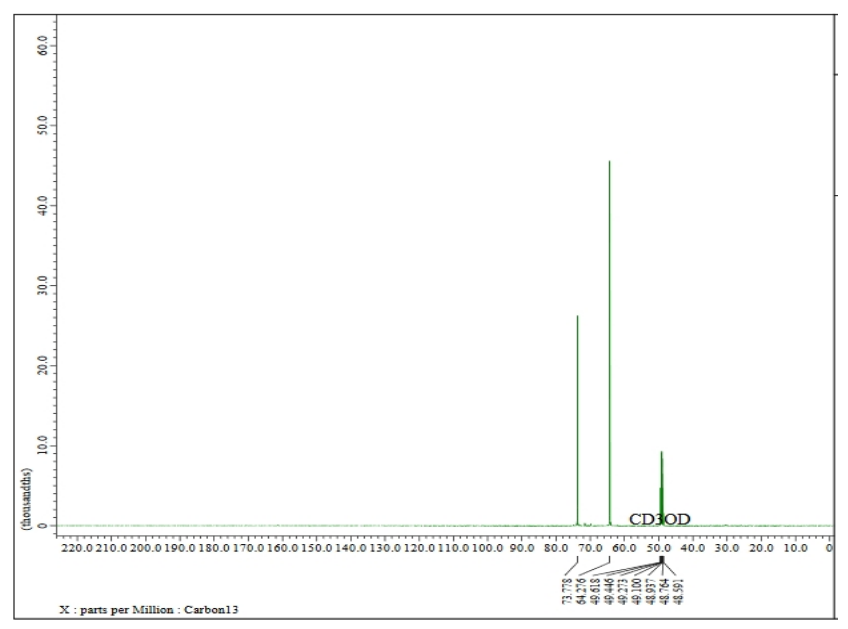

Figure $9 .{ }^{13} \mathrm{C}-\mathrm{NMR}$ spectrum syntesis of poliol

The ${ }^{13} \mathrm{C}$-NMR spectrum is shown in Figure $9 .{ }^{13} \mathrm{C}$ NMR aims to find out the number of carbon atoms in the synthesis of cow fat polyols that are formed. Measurement with this spectrophotometer is done with methanol solvent.

$\mathrm{C}-\mathrm{H}$ bonds at $64.276 \mathrm{ppm}$ which indicate that the C$\mathrm{H}$ bond signal is still forming. Whereas in the polyol literature in general the $\mathrm{C}-\mathrm{H}$ bond signal is formed at $69.0 \mathrm{ppm}$. There is not a significant difference between the $\mathrm{C}-\mathrm{H}$ bond signal in the synthesis results with the literature.

\section{Conclusion}

The choice of catalyst and solvent influences the synthesis of polyols through the ozonation process. The best solvents are glycerol with $\mathrm{H} 2 \mathrm{SO} 4$ catalyst and ozone levels of 5.480 grams. 


\section{Acknowledge}

This research was funded by the Indonesian Ministry of Research, Technology and Higher Education for Fiscal Year 2018-2019 in the Early Career Lecturer Research Scheme with Contract Number 43/AKM/MONOPTN/2019.

\section{References}

[1] Kusworo. Izzati. M.. Kismartini.. "Inovasi Teknologi dalam Mendukung Pengembangan Sapi Potong di Indonesia", (Technological Innovations in Supporting Beef Cattle Development at Indonesia). Jurnal Pengembangan Inovasi Pertanian 1(3): 173-188. 2013.

[2] Lusiana. "Kandungan Nutrisi Daging Sapi", (Nutrional in Cow Meat). [Online] Available at: $\quad$ https://m.detik.com/food/info-sehat/d3295812/kandungan-nutrisi-daging-sapi [Accessed 28 03 2019]. 2016

[3] Lawrie and David Ledward. "Lawrie's Meat Science 7edition. Food Science". Technology and Nutrition. 9781845691615. 2006

[4] Gala. S. "Sintesa Poliol dari Minyak Sawit dengan Reaksi Epoksidasi dan Hidroksilasi", (Synthesisi of Polyol from Palm Oil with Epoxidation and Hydroxylation Reaction). Jurnal Chemica (12):36-43. 2011

[5] Kamikaze. D.. "Studi Awal Pembuatan Sabun Menggunakan Campuran Lemak Abdomen Sapi (Tallow) dan Curd Susu Akfir", (Preliminary Study of Soap making using a mixture of Cow Abdomen Fat and Akfir Milk Curd).. Jurusan Ilmu Produksi Ternak Fakultas Pertenakan IPB. 2002.
[6] Adha. M. R.. dan Gibson. D. "Studi Awal Sintesis Biopoliol dari Lemak Sapi (Tallow) Melalui Proses Ozonasi”, (Initial Studies of Biopolyol Synthesis from Broom Fat through Ozonation). Laporan Penelitian Jurusan Teknik Kimia Institut Teknologi indonesia. 2019.

[7] Murniati, Handayani, dan Kumulasari. "Pengaruh Jenis Katalis pada sintesis Poliol dari Minyak Biji Kenari (Canarium commune) dengan Metode Epoksidasi”. (Effect of Catalyst in Synthesis Polyol Core of Oil Seeds Kenari, Canarium commune, Methode Epoxidation). Jurnal Penelitian UNRAM (18):1. 2014

[8] La Ifa. "Pengaruh jenis alkohol terhadap hidroksilasi pada pembuatan poliol dari minyak sawit". (Effect of Type Alcohol Hydroxylation on The Manufacture of Polyols from Palm Oil). Prosiding simposium nasional polimer VI.. 2015.

[9] Galuh and Hanafi. "Pengaruh Konsentrasi Katalis dan Perbandingan Molaritas Reaktan pada Sintesis Senyawa $\alpha$-Monolaurin".(Effect of Catalyst Concentration and Comparison of Reactant Molarity Synthesis of $\alpha$ Monolaurin Compounds). Reaktor (12):2.2008

[10] Rengga, Wara dan Rosidah Erlis. "Biodiesel dari Campuran Lemak Sapi (Beef Tallow) dan Minyak Sawit". (Biodiesel from Beef Tallow and Palm Oil).Jurnal Bahan Alam Terbarukan. 1(1).2012

[11] Haifan. M.. "Review Kajian Aplikasi Teknologi Ozon untuk Penanganan Buah", (Review of Ozone Technology Applications for Fruit Handling). Sayuran dan Hasil Perikanan. Jurnal IPTEK. (1):18-19. 2017.

[12] Benecke. "Bio-Polyols for Bio-Lubricant and BioPolymer and Methods for The Preparation Thereof. United States Patent. US 2015/0087850 A1. 2015. 